\title{
molecules
}

ISSN 1420-3049

www.mdpi.com/journal/molecules

Article

\section{Organically Modified Silica with Pyrazole-3-carbaldehyde as a New Sorbent for Solid-Liquid Extraction of Heavy Metals}

Smaail Radi ${ }^{1,2, *}$, Said Tighadouini ${ }^{1}$, Maryse Bacquet ${ }^{3}$, Stéphanie Degoutin ${ }^{3}$, Francine Cazier ${ }^{4}$, Mustapha Zaghrioui ${ }^{5}$ and Yahia N. Mabkhot ${ }^{6}$

1 Laboratoire de Chimie Appliquée et Environnement (LCAE), Faculté des Sciences, Université Mohamed I, Oujda 60 000, Morocco

2 Centre de l'Oriental des Sciences et Technologies de l'Eau (COSTE), Université Med I, Oujda 60 000, Morocco

3 Unité Matériaux et Transformations UMR8207 (UMET), Equipe Ingénierie des Systèmes Polymères, Université des Sciences et Technologies de Lille, Bâtiment C6 salle 119-59655 Villeneuve d'Ascq, France

4 Université Lille Nord de France, F-59000 Lille, Unité de Chimie Environnementale et Interactions sur le Vivant, 145 Avenue M. Schuman F-59140 Dunkerque, France

5 Laboratoire GREMAN CNRS-UMR 7347 IUT de BLOIS, Université François-Rabelais de Tours, 15 rue de la Chocolatrie 41029 Blois, France

6 Department of Chemistry, Faculty of Science, King Saud University, P.O. Box 2455, Riyadh 11451, Saudi Arabia

* Author to whom correspondence should be addressed; E-Mail: radi_smaail@yahoo.fr; Fax: +212-536-500-603.

Received: 3 December 2013; in revised form: 17 December 2013 / Accepted: 19 December 2013 / Published: 24 December 2013

\footnotetext{
Abstract: A new chelating matrix, SiNP, has been prepared by immobilizing 1.5-dimethyl-1H-pyrazole-3-carbaldehyde on silica gel modified with 3-aminopropyltrimethoxysilane. This new chelating material was well characterized by elemental analysis, FT-IR spectroscopy, cross polarization magic angle spinning solid state ${ }^{13} \mathrm{C}$-NMR, nitrogen adsorption-desorption isotherm, BET surface area, BJH pore size, and scanning electron microscopy (SEM). The new product exhibits good chemical and thermal stability as determined by thermogravimetry curves (TGA). The new prepared material was used as an adsorbent for the solid-phase extraction (SPE) of $\mathrm{Pb}$ (II), $\mathrm{Cd}(\mathrm{II}), \mathrm{Cu}$ (II) and $\mathrm{Zn}$ (II) from aqueous solutions using a batch method, prior to their determination by flame
} 
atomic adsorption spectrometry. The adsorption capacity was investigated using kinetics and $\mathrm{pH}$ effects. Common coexisting ions did not interfere with separation and determination.

Keywords: chemically modified $\mathrm{SiO}_{2}$; synthesis; characterization; adsorption; $\mathrm{Pb}(\mathrm{II})$; $\mathrm{Cd}(\mathrm{II}) ; \mathrm{Cu}(\mathrm{II}) ; \mathrm{Zn}(\mathrm{II})$

\section{Introduction}

Environment pollution by heavy metals has caused lately much concern because of their general and specific toxicities. The most toxic heavy metals, namely lead, cadmium, copper and zinc, can be distinguished from other pollutants, because they cannot be degraded naturally, but rather accumulate in living organisms. Therefore they cause different diseases and disorders, even at low concentrations [1-6]. Therefore, determination of heavy metals in environmental and biological materials is an important screening procedure in environmental pollution and occupational exposure studies.

Traditionally, extraction is carried out liquid-liquid extraction, co-precipitation, and ion exchange, etc. These methods have non-economic disadvantages. They often require large amount of high purity organic solvents, some of which are themselves harmful to health and cause environmental problems. Nowadays, several methods are used for pretreatment of the samples. Solid phase extraction (SPE) [7-12], has commonly been used as a technique for pre-concentration/separation of various inorganic and organic species. SPE has several major advantages that include higher enrichment factors, simple operation, safety with respect to hazardous samples, high selectivity, lower cost and less time, the ability to combine it with different modern detection techniques [13].

A variety of ligands or functional groups are immobilized onto a solid support matrix as a solid phase extractant for the purpose of extraction and enrichment of trace metal ions from environmental samples. Silica gel is of great importance as a solid support because it possesses some definite advantages [14]. The silica support is chosen for its high surface area, high mechanical and thermal stability. In addition, it is easily modified [15], by reacting with organofuctionalized silanes through its surface silanol groups. These covalently bonded organic groups are highly stable and resistant to removal from the surface by organic solvents or water [16]. To this end, a great number of organic molecules were immobilized on silica gel surface, xylenol orange [17], 2-thiophenecarboxaldehyde [18], di(n-propyl)thiuram disulfide [19], 4-acylpyrazolone [20], aminothioamidoanthraquinone [21], 1,8-dihydroxyanthraquinone [22], murexide [23], oxime derivatives [24], resacetophenone [6], diphenyldiketone monothiosemicarbazone [25]. These systems can be operated indefinitely without loss of the expensive organic molecules. Their potential applications are attributable essentially to the nature of the grafted ligands. Indeed, the most commonly attached molecules have chelating ability due to their donor atoms, such as oxygen, nitrogen and sulphur, which have a large capability to form complexes with a series of metal ions, leading in some cases, to distinguishable selective extraction properties.

In this context, for many years, the ability of pyrazole and its derivatives to act as ligands with $\mathrm{sp}^{2}$ hybrid nitrogen donors have been the research subjects of many coordination chemists. This is evident from the large number of articles on this topic, several of them being reviews [26-28]. In continuation of our work in this field [29-32], this paper describes the synthesis and the characterization of a new 
material obtained by grafting onto porous silica functionalized compounds which can act as in a $N, N^{\prime}$-bidentate fashion [33,34] forming five membered chelating rings. The immobilization of this ligand on silica gel was carried out with a long arm spacer in order to facilitate the contact between the receiver and the metal ion. The new chelating material was well characterized and its adsorption capacities towards highly toxic heavy metals ions such as $\mathrm{Pb}(\mathrm{II}), \mathrm{Cd}(\mathrm{II}), \mathrm{Cu}$ (II) and $\mathrm{Zn}$ (II) was investigated and the extracted amounts of metals ions were determined by atomic absorption measurements. This new material presents high adsorption of lead compared to the other tested metals ions.

\section{Results and Discussion}

\subsection{Linker Synthesis}

The synthetic procedure for the new chelating material is summarized in Scheme 1. The preparation involves the reaction of activated silica gel with 3-aminopropyltrimethoxysilane in toluene to install amino groups attached to the silica surface [35]. These $\mathrm{NH}_{2}$-groups onto the silica surface were then reacted with 1,5-dimethyl-1 $H$-pyrazole-3-carbaldehyde under mild conditions (reflux, atmospheric pressure and $8 \mathrm{~h}$ ) using anhydrous ethanol as solvent, to form the new chelating sorbent SiNP.

Scheme 1. The synthesis route of modified chelating material.



\subsection{Characterization}

\subsubsection{Elemental Analysis}

The elemental analysis of carbon and nitrogen (not present in the starting activated silica) of aminopropylsilica $\mathrm{SiNH}_{2}$ makes it possible to characterize and highlight the introduced organic group on the silica surface. The microanalysis results $(\% \mathrm{C}=4.46, \% \mathrm{~N}=1.66$ and $\% \mathrm{H}=1.27)$ suggests that two methoxy groups were substituted by silanol. The final SiNP-Schiff base material showed also an increase in the percentage of $\mathrm{C}, \mathrm{N}$ and $\mathrm{H}(\% \mathrm{C}=5.32, \% \mathrm{~N}=1.90$ and $\% \mathrm{H}=1.34)$, which means that the pyrazole unit was immobilized on the silica gel surface. 


\subsubsection{FT-IR Characterization}

To confirm the presence of functional groups in the material, FT-IR spectra were performed for free silica gel, $\mathrm{SiNH}_{2}$ and SiNP materials (Figure 1). The sharp features around $1,100 \mathrm{~cm}^{-1}$ indicated Si-O-Si stretching vibrations. The presence of adsorption water was reflected by $v(\mathrm{OH})$ vibration around 3,446 and $1,620 \mathrm{~cm}^{-1}$. The bonds around $970 \mathrm{~cm}^{-1}$ resulted from Si-O vibration [36]. Compared to free silica gel, the spectrum of $\mathrm{SiNH}_{2}$ exhibits some new peaks such as the $\mathrm{CH}_{2}$ vibration band at $2,691 \mathrm{~cm}^{-1}$ and the $\mathrm{NH}_{2}$ vibration at $1,560 \mathrm{~cm}^{-1}$ [37,38]. The characteristic features of SiNP compared with $\mathrm{SiNH}_{2}$ were the disappearance of the adsorption band at $1,560 \mathrm{~cm}^{-1}$ due to the reaction of the primary amine $\left(-\mathrm{NH}_{2}\right)$ and the appearance of a new characteristic bond around $1,500 \mathrm{~cm}^{-1}$ resulting from $\mathrm{C}=\mathrm{N}$ and $\mathrm{C}=\mathrm{N}$ vibrations, which confirms the anchoring of the organic molecule onto the silica surface.

Figure 1. FT-IR Spectra of free silica ( $\mathrm{SiG}), 3$-aminopropylsilica $\left(\mathrm{SiNH}_{2}\right)$ and $(\mathrm{SiNP})$.

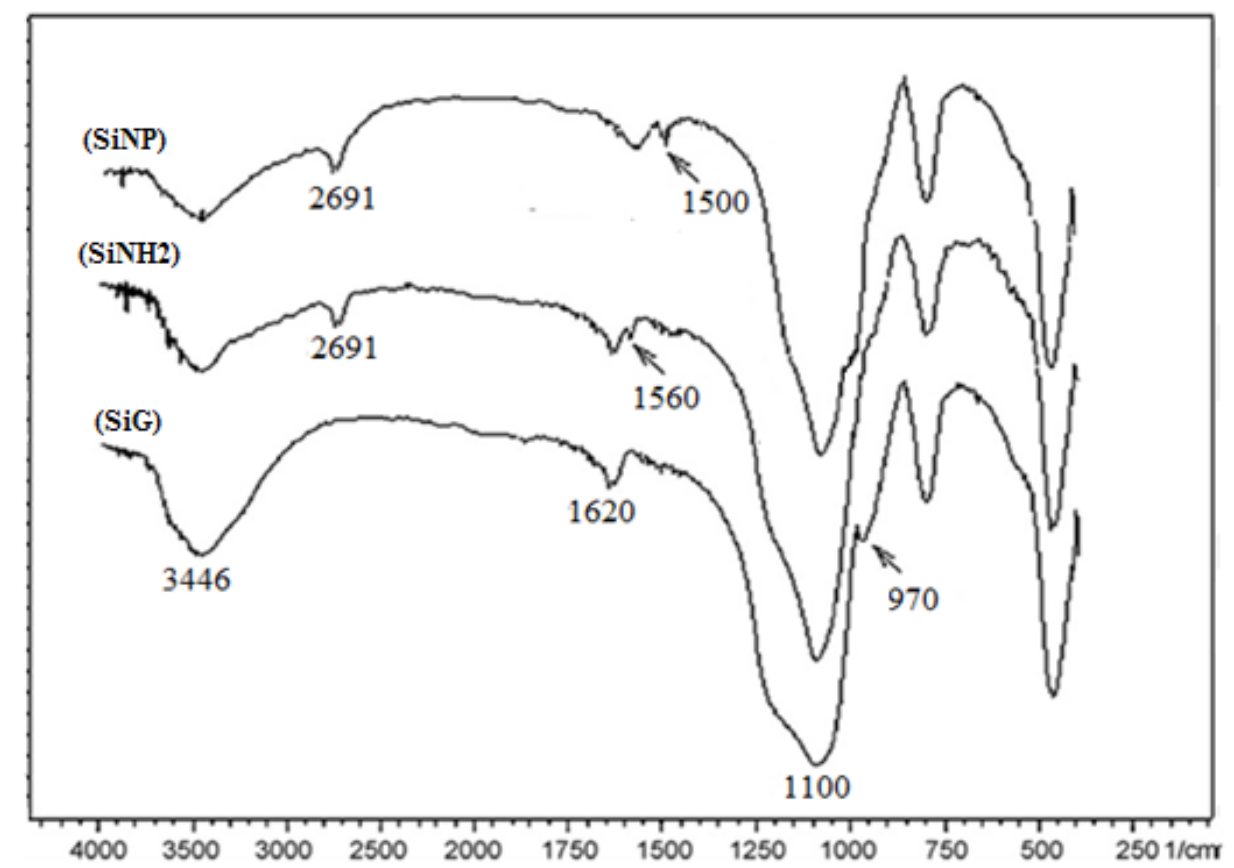

\subsubsection{Scanning Electron Micrographs}

Scanning electron micrographs (SEM) were obtained on the free silica and chemically modified silicas in order to detect differences in their surfaces. SEM of silica gel, $\mathrm{SiNH}_{2}$ and SiNP in Figure 2 were obtained at $300 \times$ and 1,200× magnification. The SEM was displayed to clarify the un-agglomeration of the silica gel particles after treatment to support the claiming of regular distribution of the functional group on the whole surface. It was evident that the loaded functional groups were distributed on the whole surface that made the surface of the product SiNP become rough.

\subsubsection{TGA Analysis and Thermal Stability}

The thermogravimetric curves for all surfaces enable the establishing of information on thermal stability and also to confirm the amount of the compounds immobilized, as shown in Figure 3. The 
profile indicates a degradation process between 146 and $800{ }^{\circ} \mathrm{C}$ which confirms the high thermal stability for the prepared material.

Figure 2. SEM images of free silica (A), $\mathrm{SiNH}_{2}(\mathbf{B})$ and $\operatorname{SiNP}(\mathbf{C})$.

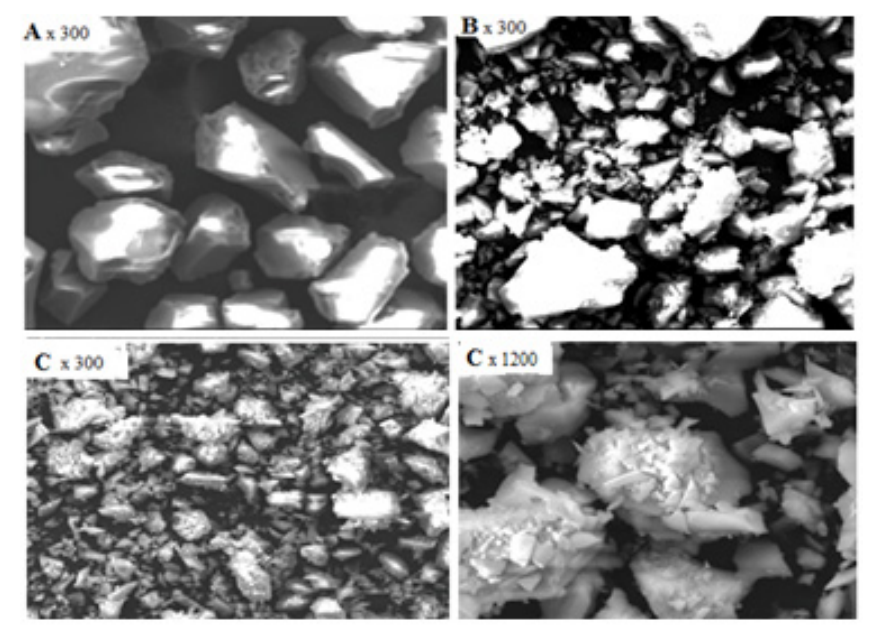

Figure 3. Thermogravimtric curves of free silica (a), $\mathrm{SiNH}_{2}(\mathbf{b})$ and $\operatorname{SiNP}(\mathbf{c})$.

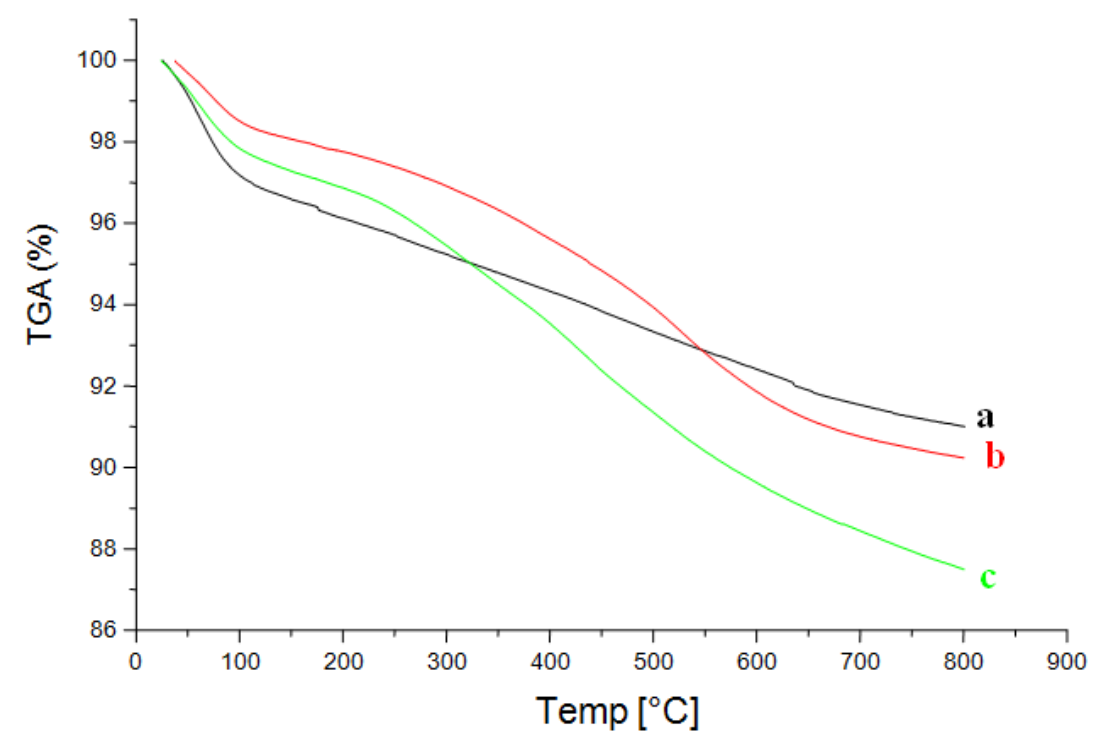

The free silica presents a first mass loss stage of $3.15 \%$ in the interval from room temperature to $110{ }^{\circ} \mathrm{C}$, assigned to physically adsorbed water and a second loss of $5.85 \%$ from 110 to $800{ }^{\circ} \mathrm{C}$ assigned to condensation of the free silanol groups which causes siloxane bond formation ( $\mathrm{Si}-\mathrm{O}-\mathrm{Si}$ ) [39,40]. Again two distinct mass loss steps were detected for the $\mathrm{SiNH}_{2}$ sample. The first one, a small mass loss of $1.56 \%$ in the room temperature to $100{ }^{\circ} \mathrm{C}$ range is attributed to the remaining silanol hydration water, as a consequence of the use of these groups in the immobilization process. On the other hand, a pronounced mass loss increase of $9.77 \%$ was observed for the second step, between 208 and $800{ }^{\circ} \mathrm{C}$, which corresponds to the organic matter added onto the surface during immobilization. The final SiNP material presented two distinct mass loss stages. Following the preceding interpretation, the first mass loss of $2.27 \%$ in the $25-102{ }^{\circ} \mathrm{C}$ range is assigned to adsorbed water, and other mass loss of $12.49 \%$ between 231.47 and $800{ }^{\circ} \mathrm{C}$ is attributed to the decomposition of the pyrazole fraction immobilized on 
the surface of silica gel, together with the condensation of the remaining silanol groups. The pronounced increase in mass loss reflects the higher amount of the anchored organic groups.

\subsection{5. ${ }^{13} \mathrm{C}-\mathrm{NMR}$ Characterization}

Important features related to the immobilization of pendant groups on the inorganic structure of the formed hybrid can be obtained through solid state ${ }^{13} \mathrm{C}-\mathrm{NMR}$ spectroscopy, as shown in Figure 4 . The signals observed for 3-aminopropyl-silica $\mathrm{SiNH}_{2}$ at $\delta=9.02,24.79$ and $42.62 \mathrm{ppm}$ have been assigned to the propyl carbon $\mathrm{Si}-\mathrm{CH}_{2},-\mathrm{CH}_{2}-$ and $\mathrm{N}-\mathrm{CH}_{2}$, respectively. The signal at $50.62 \mathrm{ppm}$ was assigned to the unsubstituted methoxy group as confirmed by microanalysis.

Figure 4. ${ }^{13} \mathrm{C}$-NMR spectra of 3-aminopropylsilica $\left(\mathrm{SiNH}_{2}\right)$.

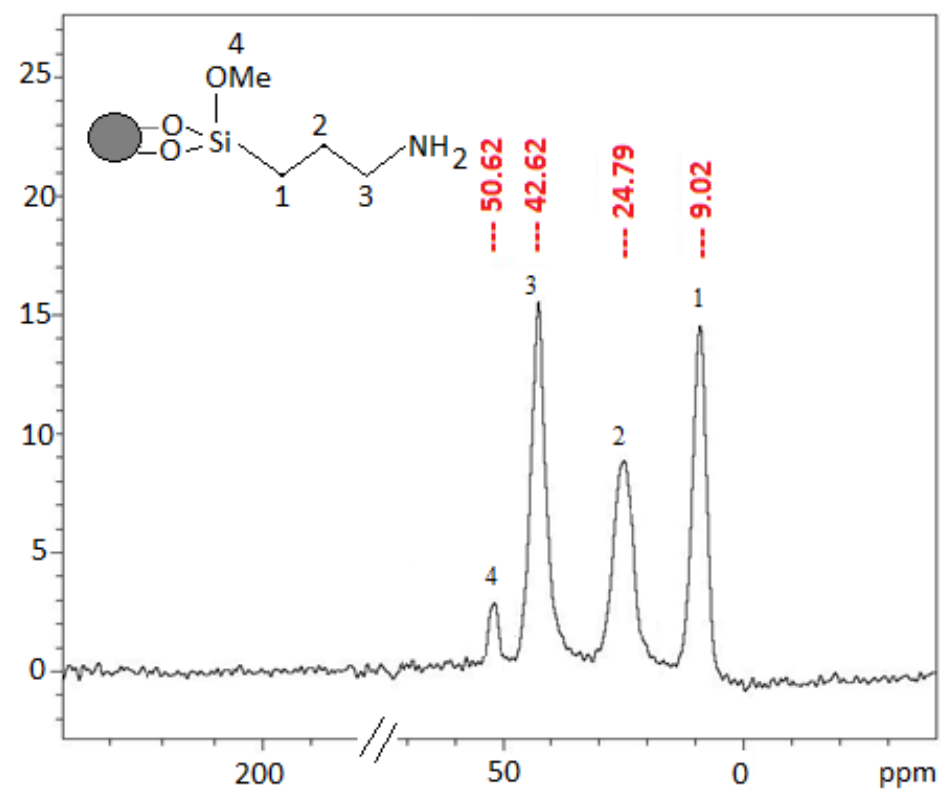

\subsubsection{Chemical Stability}

Chemical stability of the newly synthesized material SiNP was examined in various acidic and buffer solutions ( $\mathrm{pH}$ 1-7). No change in the material structure was observed even after $24 \mathrm{~h}$ of contact. The high stability exhibited by the attached organofunctional group is presumably due to the pendant group. It has been shown that when the length of the hydrocarbon bridge was more than two methylene groups, the rupture of $\mathrm{Si}-\mathrm{C}$ bond did not occur in a mineral acid medium, due to the length of the chain; longer chains no longer have a functional handle that can undergo $\beta$-elimination of the Si cation $[41,42]$.

\subsubsection{Surface Properties}

To show the porosity changes of the silica induced by the introduction of 3-aminopropyl and pyrazole unit, we measured the surface area $S_{\text {BET }}$ (Brunauer-Emmett-Teller), pore volumes, and pore diameters of both silica and its derivatives with nitrogen adsorption-desorption isotherms (Figure 5) and by Barrett-Joyner-Halenda $(\mathrm{BJH})$ pore diameters methods [43,44]. The density of the pendant groups covalently attached to the inorganic silica backbone changes the original characteristics of the 
surface. As shown in Table 1, the initial specific surface area $S_{\text {BET }}$ of $305.21 \mathrm{~m}^{2} \mathrm{~g}^{-1}$ and a pore volume of $0.77 \mathrm{~cm}^{3} \mathrm{~g}^{-1}$, decreases as the immobilization takes place to give $283.08 \mathrm{~m}^{2} \mathrm{~g}^{-1}$ and a pore volume of $0.69 \mathrm{~cm}^{3} \mathrm{~g}^{-1}$. A decrease in $\mathrm{S}_{\mathrm{BET}}$ is mainly due to the presence of the organic moieties that can block the access nitrogen to the silica base. On the other hand, we observed that SiNP has an additional BET surface area decrease as additional group immobilization takes place to give $236.60 \mathrm{~m}^{2} \mathrm{~g}^{-1}$, and a pore volume of $0.64 \mathrm{~cm}^{3} \mathrm{~g}^{-1}$. The decreased surface area and pore volume in SiNP are attributable to the grafted 1.5-dimethyl-1 $H$-pyrazole-3-carbaldehyde.

Figure 5. Nitrogen adsorption-desorption isotherm plots of $\mathrm{SiNH}_{2}$ and $\mathrm{SiNP}_{\text {. }}$

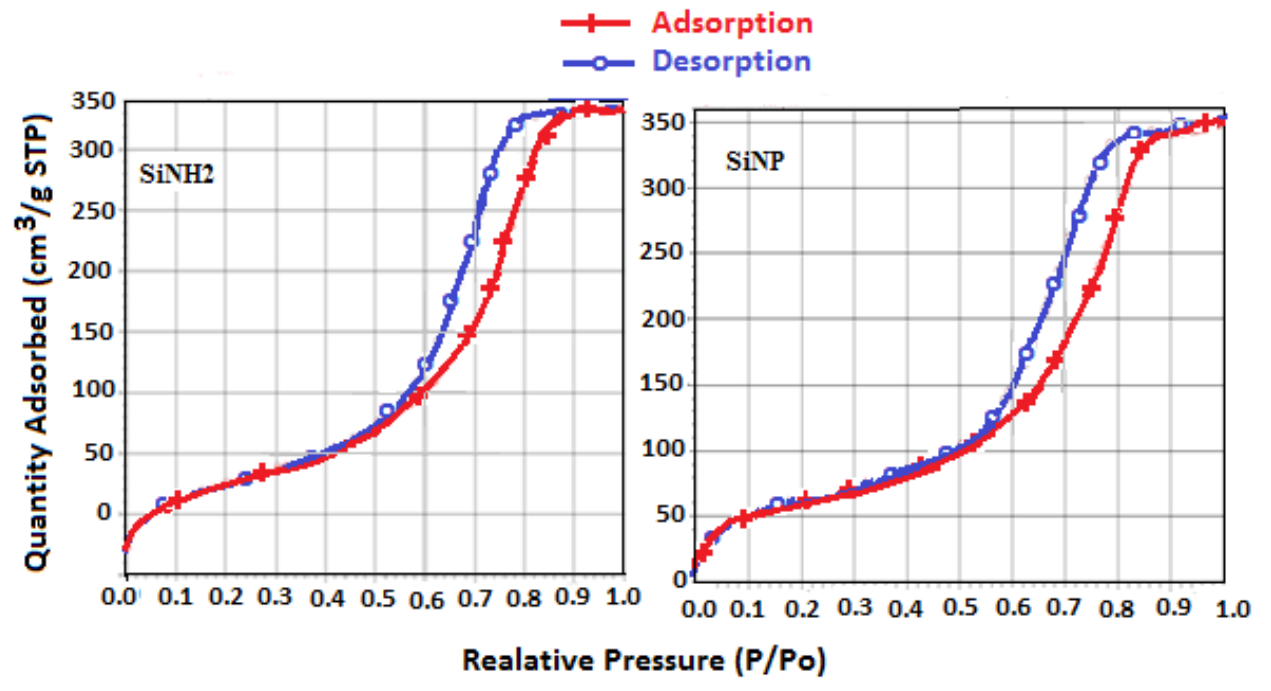

Table 1. Physical properties of silica derivatives.

\begin{tabular}{ccc}
\hline Silica derivatives & Specific surface $\mathbf{S}_{\mathbf{B E T}}\left(\mathbf{m}^{\mathbf{2}} \mathbf{g}^{\mathbf{- 1}}\right)$ & Pore volume $\left(\mathbf{c m}^{\mathbf{3}} \mathbf{g}^{-\mathbf{1}}\right)$ \\
\hline Free silica & 305.21 & 0.77 \\
$\mathrm{SiNH}_{2}$ & 283.08 & 0.69 \\
$\mathrm{SiNP}$ & 236.60 & 0.64 \\
\hline
\end{tabular}

Moreover, the nitrogen adsorption-desorption isotherm for silica derivatives, shown in Figure 5, are type IV according to the IUPAC classification and display a pronounced hysteresis for partial pressures $\mathrm{P} / \mathrm{P}_{0}>0.4$.

\subsection{Solid-Liquid Adsorption of Metal Ions by SiNP}

The effects of $\mathrm{pH}$ and shaking time on the extraction of the three metal ions were studied by the batch method. The modified silica gel $(10 \mathrm{mg})$ was equilibrated by shaking with $10 \mathrm{~mL}$ of a solution containing different concentrations of metal ions $(243.01 \mathrm{mg} / \mathrm{L}$ for $\mathrm{Pb}(\mathrm{II}), 102.93 \mathrm{mg} / \mathrm{L}$ for $\mathrm{Cd}(\mathrm{II})$, $75.63 \mathrm{mg} / \mathrm{L}$ for $\mathrm{Cu}(\mathrm{II})$ and $74.02 \mathrm{mg} / \mathrm{L}$ for $\mathrm{Zn}(\mathrm{II})$ ), for different time intervals (1, 15, $30 \mathrm{~min}$ and 1, 1.5, $2,3,4,5,6$, and $24 \mathrm{~h}$ ) and different $\mathrm{pH}$ values (1-8). The metal ions were in excess over the sorption capacity. The concentration of metal ions was determined by means of atomic absorption measurements. The amount of metal ions adsorbed by the synthesized material SiNPz from aqueous solution was calculated using the following equations [45]: 


$$
\begin{gathered}
\mathrm{Q}_{\mathrm{M}}=\left(\mathrm{C}_{0}-\mathrm{Ce}\right) \times \mathrm{V} / \mathrm{W} \\
\mathrm{Q}_{\mathrm{W}}=\mathrm{Q}_{\mathrm{M}} \times \mathrm{M}
\end{gathered}
$$

where $\mathrm{Q}_{\mathrm{M}}$ is the amount of the metal ion on the adsorbent $(\mathrm{mmol} / \mathrm{g}), \mathrm{Q}_{\mathrm{W}}$ is the amount of the metal ion on the adsorbent $(\mathrm{mg} / \mathrm{g}), \mathrm{V}$ is the volume of the aqueous solution (1), $\mathrm{W}$ is the weight of the adsorbent $(\mathrm{g}), \mathrm{C}_{0}$ the initial concentration of metal ion $(\mathrm{mmol} / \mathrm{L})$, Ce the equilibrium metal ion concentration in solution $(\mathrm{mmol} / \mathrm{L})$ and $\mathrm{M}$ the atomic weight for metals $(\mathrm{g} / \mathrm{mol})$. Analyses were performed in duplicate for each sample and the mean data are reported.

\subsubsection{Effect of $\mathrm{pH}$}

It is well-known that binding of metal ions to the chelate compounds either in solution or loaded on solid supports is mainly dependent on several factors such as the nature, charge and size of the metal ions [46,47], nature of the donor atoms and their binding characteristics [48,49], and the buffering conditions. These factors are very well documented in solution chemistry as well in solid-phase extraction of certain metals by organic chelates immobilized on the surface of solid supports such as silica gel, nanomaterials or polymeric species. Therefore, to evaluate the suitability of the newly synthesized SiNP for metal ions extraction and binding, we studied the effect of $\mathrm{pH}$ of the metal ion solution on the metal capacity values as one of the most significant controlling factors in such a process.

The adsorption properties of SiNP were investigated in the $\mathrm{pH} 1-8$ range as shown in Figure 6 . Results reveal that the metal ion uptake of the adsorbent varies significantly as the $\mathrm{pH}$ changes. At lower $\mathrm{pH}$ values, the retention of metal ions by the functionalized silica SiNP is not significant since the ligand must be almost entirely in its protonated form. As the $\mathrm{pH}$ increases, the protonation becomes weak, which enhances the chelation and adsorption of metal ions. At $\mathrm{pH}>8$, the retention of metal ions decreased because of the hydrolysis of metal ions (leading to the hydroxides of $\mathrm{M}(\mathrm{II}): \mathrm{M}(\mathrm{OH})^{+}$ and $\left.\mathrm{M}(\mathrm{OH})_{2}\right)$, this makes it difficult to distinguish between the hydrolyzed or adsorbed $\mathrm{M}(\mathrm{II})$. Therefore, the optimum $\mathrm{pH}$ for the maximum sorption of $\mathrm{Cu}$ (II) was at $\mathrm{pH} \geq 5, \mathrm{Cd}$ (II) and $\mathrm{Zn}$ (II) at $\mathrm{pH} \geq 6$ and $\mathrm{Pb}(\mathrm{II})$ at $\mathrm{pH} \geq 7$. Data are given in Table 2 .

Table 2. Metal ion uptake of $\operatorname{SiNP}\left(\mathrm{Q}_{\mathrm{w}}, \mathrm{mg} / \mathrm{g}\right)$ according to $\mathrm{pH}$.

\begin{tabular}{ccccc}
\hline $\mathbf{p H}$ & $\mathbf{P b}(\mathbf{I I})$ & $\mathbf{C d}(\mathbf{I I})$ & $\mathbf{C u}(\mathbf{I I})$ & $\mathbf{Z n ( I I )}$ \\
\hline 1 & 0 & 0 & 0 & 0 \\
2 & 3.26 & 5.99 & 0.96 & 0 \\
3 & 13.92 & 10.43 & 17.08 & 12.24 \\
4 & 52.83 & 12.66 & 18.68 & 12.25 \\
5 & 60.38 & 14.34 & 22.04 & 16.55 \\
6 & 66.14 & 25.29 & 22.1 & 19.13 \\
7 & 74.86 & 26.89 & 22.08 & 20.43 \\
8 & 74.89 & 26.93 & 22.06 & 20.43 \\
\hline
\end{tabular}


Figure 6. Adsorption kinetics of $\mathrm{Pb}(\mathrm{II}), \mathrm{Cd}(\mathrm{II}), \mathrm{Cu}(\mathrm{II})$ and $\mathrm{Zn}(\mathrm{II})$ on $\mathrm{SiNP}$.

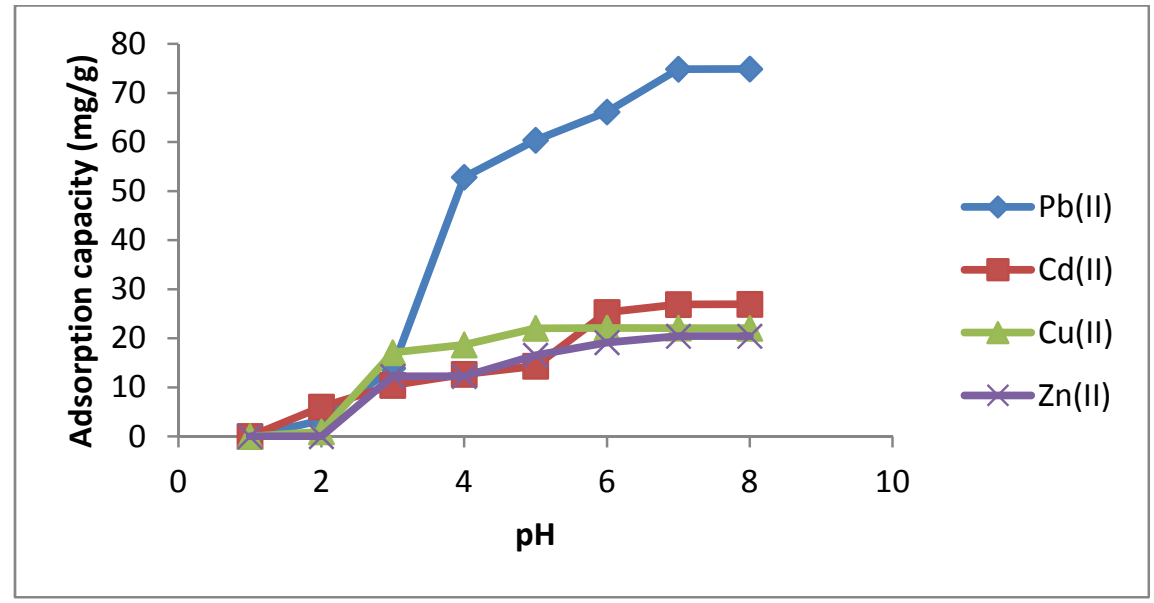

\subsubsection{Effect of Stirring Time}

The stirring time used for the adsorption of the metal ion by the modified silica gel and the attainment of equilibrium conditions is of considerable importance. Effect of stirring time on the adsorption of $\mathrm{Pb}(\mathrm{II}), \mathrm{Cd}(\mathrm{II}), \mathrm{Cu}(\mathrm{II})$ and $\mathrm{Zn}(\mathrm{II})$ by $\mathrm{SiNP}$ was studied by batch experiments. As can be seen from Figure 7, the kinetic curves of $\mathrm{Pb}$ (II), $\mathrm{Cd}$ (II), $\mathrm{Cu}$ (II) and $\mathrm{Zn}$ (II) showed that the adsorption was rapid and the plateau was reached after about $30 \mathrm{~min}$ of contact. The rapid adsorption of different metal ions suggests that the two nitrogen active donor atoms on the modified silica gel surface are oriented in such a way that their accessibility is not hindered and consequently, fast interaction with the free metal ions present in solution is feasible. Indeed, the two nitrogens (of the grafted pyrazole and of the imine) act as a convergent chelating bidentate donor. The term convergent refers to the nitrogen donor atoms coordinating to the same metal center, thus leading to a five-membered ring which is part of several such rings when the whole ligand is considered. It is well known that five-membered ring chelates are more stable than six-membered and four-membered ones [50]. The rapid kinetics have a significant practical importance, as it will facilitate smaller reactor volumes ensuring efficiency and economy.

Figure 7. Effect of $\mathrm{pH}$ value on the retention of $\mathrm{Pb}(\mathrm{II}), \mathrm{Cd}(\mathrm{II}), \mathrm{Cu}(\mathrm{II})$ and $\mathrm{Zn}(\mathrm{II})$ on $\mathrm{SiNP}$.

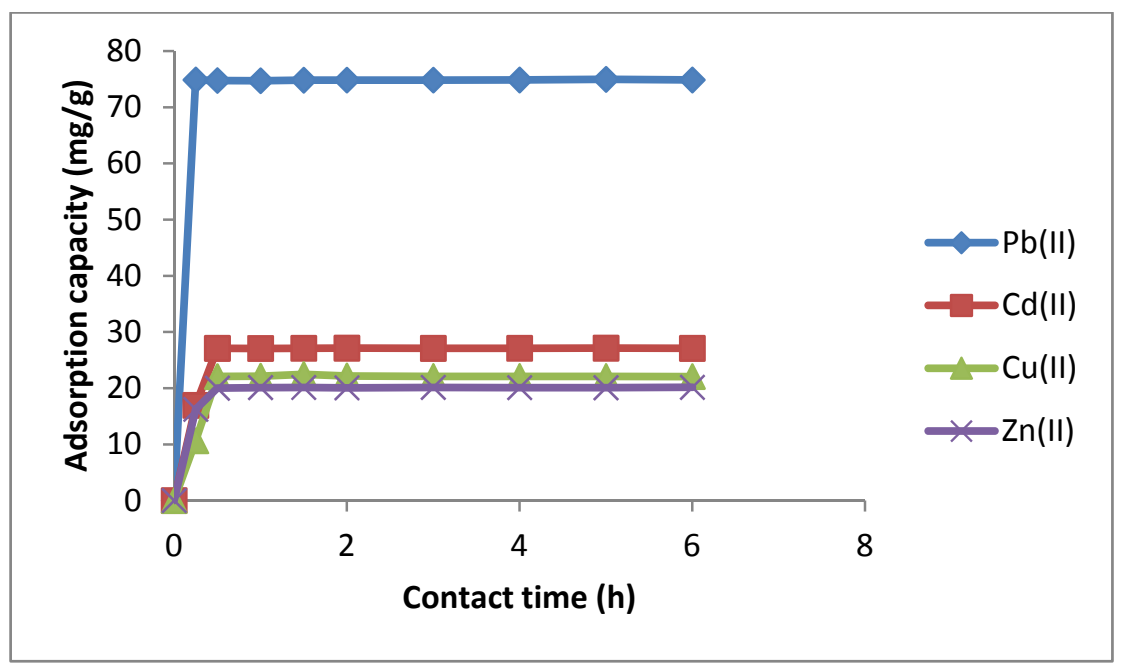


The variation in sorption capacities of various metal ions probably arises due to their size, degree of hydration, and binding constants of their complexes with the matrix.

\subsubsection{Effect of Coexisting Ions}

It is well know that metal cations and acyclic pyrazolic compounds do not complex alkali metal cations at all, while the macrocyclic pyrazolic ligands form complexes both transition and alkali metals [51-53]. Thus, the effects of common coexisting ions in water samples on the recovery of each metal were also studied. In these experiments, $50 \mathrm{~mL}$ of a solution containing $0.1 \mu \mathrm{g} / \mathrm{mL}$ of a metal ion and various amounts of interfering ions were treated according to the recommended procedure. An ion was considered to interfere when its presence produced a variation in the extraction recovery of sample more than $\pm 5 \%$. The results show that in excess of 10,000 -fold, the $\mathrm{Li}^{+}, \mathrm{K}^{+}, \mathrm{Na}^{+}, \mathrm{Ca}^{2+}$ and $\mathrm{Mg}^{2+}$ ions show no significant interferences in the extraction and determination of each $\mathrm{Pb}(\mathrm{II}), \mathrm{Cd}(\mathrm{II}), \mathrm{Cu}(\mathrm{II})$ and $\mathrm{Zn}(\mathrm{II})$ metals. As can be seen, SiNP has a high tolerance limit for alkali and alkaline earth metals. This is particularly useful for the analysis of transition elements of group 12 and $\mathrm{Pb}(\mathrm{II})$, in natural water samples, for example seawater, which contains large amounts of alkali and alkaline earth metal ions.

\subsubsection{Comparison with Alternative Materials}

Table 3 shows the adsorption of $\mathrm{Pb}(\mathrm{II})$, by other material reported in the literature. It is clear that the functionalized silica described in this work presents further improvement and shows better values and higher affinity for the effective adsorption for $\mathrm{Pb}(\mathrm{II})$ and other metals under study.

Table 3. Comparison of SiNP with other reported sorbents for $\mathrm{Pb}(\mathrm{II})$ absorption.

\begin{tabular}{lcc}
\hline Support: silica gel/ligand & Reference & Capacity $\left(\mathbf{m g} \mathbf{~ o f ~} \mathbf{~ b b}^{\mathbf{2 +}} / \mathbf{g}\right.$ of silica) \\
\hline Pyrazol-3-ylimine (this work) & - & 74.89 \\
Gallic acid & {$[54]$} & 12.63 \\
Ethylediamine derivatives & {$[55]$} & 38.12 \\
C,N-pyridylpyrazole & {$[56]$} & 09.5 \\
Thiophene & {$[57]$} & 11.3 \\
Acid red 88 & {$[58]$} & 03.35 \\
Dithizone & {$[59]$} & 08.28 \\
Resacetophenone & {$[6]$} & 13.79 \\
Tris(2-aminoethyl) amine & {$[60]$} & 64.61 \\
3-Aminopropytriethoxysilane $\left(\mathrm{SiNH}_{2}\right)$ & {$[61]$} & 23.70 \\
\hline
\end{tabular}

\section{Experimental}

\subsection{General Information}

All solvents and other chemicals (purity $>99.5 \%$, Aldrich, Saint-Louis, MO, USA) were of analytical grade and used without further purification. Silica gel (E. Merck, Darmstadt, Germany) with particle size in the range of 70-230 mesh, median pore diameter $60 \AA$, was activated before use by heating it at $160{ }^{\circ} \mathrm{C}$ during $24 \mathrm{~h}$. The silylating agent 3-aminopropyltrimethoxtsilane (Janssen Chimica, Geel, Belgium) was used without purification. All metal ions were determined by atomic adsorption 
measurements were performed by a Spectra Varian A.A. 400 spectrophotometer (Oujda, Morocco). The $\mathrm{pH}$ value was controlled by a $\mathrm{pH}$ 2006, J. P. Selecta s. a. (Barcelona, Span); Elemental analyses were performed by the Microanalysis Centre Service (CNRS, Lille, France). FT-IR spectra were obtained with a Perkin Elmer System 2000 instrument (Oujda, Morocco). SEM image were obtained on an FEI-Quanta 200 (Lille, France). The mass loss determinations were performed in 90:10 oxygen/nitrogen atmospheres on a Perkin Elmer Diamond TG/DTA, at a heating rate of $10{ }^{\circ} \mathrm{C} \min ^{-1}$ (Blois, France). The ${ }^{13} \mathrm{C}-\mathrm{NMR}$ spectrum of the solid state was obtained with a CP MAX CXP $300 \mathrm{MHz}$ instrument (Lille, France). The specific area of the modified silica was determined by using the BET equation. The nitrogen adsorption-desorption was obtained by means of a Thermoquest Sorpsomatic 1990 analyzer (Lille, France), after the material had been purged in a stream of dry nitrogen. Molecular weights were determined on a JEOL JMS DX-300 Mass Spectrometer (CNRST, Rabat, Morocco).

\subsection{Synthesis of 3-Aminopropylsilica $\left(\mathrm{SiNH}_{2}\right)$}

The first stage in the preparation was the reaction between the silylating agent and silanol groups on the silica surface. Activated silica gel $\mathrm{SiO}_{2}(25 \mathrm{~g})$ suspended in dried toluene $(150 \mathrm{~mL})$ was refluxed and mechanically stirred under nitrogen atmosphere for $2 \mathrm{~h}$. To this suspension, aminopropyltrimethoxysilane $(10 \mathrm{~mL})$ was added dropwise and the mixture was kept under reflux for $24 \mathrm{~h}$. The solid was filtered, washed with toluene and ethanol. It was then Soxhlet extracted with a 1:1 mixture of ethanol and dichloromethane for $12 \mathrm{~h}$, to remove the silylating reagent residue. The immobilized silica gel, named $\mathrm{SiNH}_{2}$, was dried under vacuum at room temperature.

\subsection{Synthesis of 1.5-Dimethyl-1H-pyrazole-3-carbaldehyde}

(1.5-Dimethyl-1H-pyrazol-3-yl) methanol [62,63] (1.2 g, $9.52 \mathrm{mmol})$ was dissolved in 1,4-dioxane $(100 \mathrm{~mL})$. Activated manganese dioxide $(21.88 \mathrm{~g})$ was added to the solution and the suspension was stirred under reflux for $5 \mathrm{~h}$. The reaction was monitored by TLC (alumina, $\mathrm{CH}_{2} \mathrm{Cl}_{2}$ as eluent). The hot suspension was filtered and the solid $\mathrm{MnO}_{2}$ was washed with boiling 1,4-dioxane. The solvent was removed on a rotary evaporator to give the expected product as a liquid $(0.7 \mathrm{~g}$, yield 59.23\%). $\mathrm{Rf}=47.51) .{ }^{1} \mathrm{H}-\mathrm{NMR}\left(\mathrm{CDCl}_{3}\right) \delta \mathrm{ppm}: 2.13\left(\mathrm{~s}, 3 \mathrm{H}, \mathrm{C}-\mathrm{CH}_{3}\right), 3.84\left(\mathrm{~s}, 3 \mathrm{H}, \mathrm{N}-\underline{\mathrm{C}}_{3}\right), 6.51(\mathrm{~s}, 1 \mathrm{H}, \mathrm{Pz}-\mathrm{H})$, $9.84\left(\mathrm{~s}, 1 \mathrm{H}, \mathrm{C}-\underline{\mathrm{H}}\right.$, aldehyde). ${ }^{13} \mathrm{C}-\mathrm{NMR}\left(\mathrm{CDCl}_{3}\right) \delta \mathrm{ppm}: 11.20\left(1 \mathrm{C}, \mathrm{C}-\underline{\mathrm{CH}}_{3}\right), 67.05\left(1 \mathrm{C}, \mathrm{N}-\mathrm{CH}_{3}\right)$, $105.19\left(1 \mathrm{C}, \mathrm{CH}_{3}-\mathrm{C}=\underline{\mathrm{C}}-\right), 140.88\left(1 \mathrm{C}, \underline{\mathrm{C}}-\mathrm{CH}_{3}\right), 149.19$ (1C, N=ㄷ-), 186.40 (1C, C-H, aldehyde). IR $v(\mathrm{C}=\mathrm{O})=1691 \mathrm{~cm}^{-1}$. MS $m / z=124\left(\mathrm{M}^{+}\right)$.

\subsection{Synthesis of ((1,5-Dimethyl-1H-pyrazol-3-yl)methylene)imine-Substituted Silica (SiNP)}

For the synthesis of SiNP, a mixture of 3-aminopropylsilica $\left(\mathrm{SiNH}_{2}, 5 \mathrm{~g}\right)$ and 1.5-dimethyl-1Hpyrazole-3-carbaldehyde $(3 \mathrm{~g})$ in dry ethanol $(60 \mathrm{~mL})$ was stirred at reflux for $8 \mathrm{~h}$. After being filtered, the solid product was Soxhlet extracted with acetonitrile, methanol and dichloromethane for $12 \mathrm{~h}$, respectively. The product was then dried under vacuum at $70{ }^{\circ} \mathrm{C}$ over $24 \mathrm{~h}$. 


\subsection{Batch Experiments}

The effects of solution $\mathrm{pH}$ and contact time on the sorption of metal ions were evaluated on batch method. A suspension of adsorbent (SiNP, $10 \mathrm{mg}$ ) in metal solution $(10 \mathrm{~mL})$ containing different concentrations of metal ions $(243.01 \mathrm{mg} / \mathrm{L}$ for $\mathrm{Pb}(\mathrm{II}), 102.93 \mathrm{mg} / \mathrm{L}$ for $\mathrm{Cd}(\mathrm{II}), 75.63 \mathrm{mg} / \mathrm{L}$ for $\mathrm{Cu}$ (II) and $74.02 \mathrm{mg} / \mathrm{L}$ for $\mathrm{Zn}(\mathrm{II})$ ), was mechanically stirred at room temperature for $1 \mathrm{~min}$ to $24 \mathrm{~h}$ at $25{ }^{\circ} \mathrm{C}$ and under various $\mathrm{pH}$ conditions. The mixture was then filtered off and the amount of metal ion in the filtrate solution was determined by atomic adsorption measurement using standard solutions for calibration. Analyses were performed in duplicate for each sample and only the mean data are reported.

\section{Conclusions}

1.5-Dimethyl-1H-pyrazole-3-carbaldehyde was successfully bound on the silica surface after modification by 3-aminopyltrimethoxysilane. The structural, chemical and metal ion adsorption properties of this newly prepared sorbent was investigated. The adsorbent showed a high adsorption capacity towards $\mathrm{Pb}(\mathrm{II}), \mathrm{Cd}(\mathrm{II}), \mathrm{Cu}(\mathrm{II})$ and $\mathrm{Zn}(\mathrm{II})$ metal ions, with the best adsorption capacity of SiNP being $74.89 \mathrm{mg} / \mathrm{g}$ for $\mathrm{Pb}(\mathrm{II})$ ions. The new material was well characterized by elemental analysis, FT-IR spectra, ${ }^{13} \mathrm{C}-\mathrm{NMR}$, nitrogen adsorption-desorption isotherm, BET surface area, B.J.H. pore sizes, thermogravimetry curves (TGA), and scanning electron microscopy (SEM). The new chelating surface exhibits good chemical and thermal stability. The sample was easily regenerated by soaking the sample in $6 \mathrm{~N} \mathrm{HCl}$ for a few minutes $(5-10 \mathrm{~mL}$ of $6 \mathrm{~N} \mathrm{HCl}$ per $\mathrm{g}$ of support). The sorbent was regenerated five times, and showed no significant decrease in extraction percentage.

\section{Acknowledgments}

The authors extend their appreciation to the Deanship of Scientific Research at King Saud University for funding the work through the research group project Number RGP-VPP-007. The authors gratefully acknowledge Bertrand REVEL, Research Engineer in the common center of NMR measurements of the University of Lille 1, for his assistance in recording the ${ }^{13} \mathrm{C}-\mathrm{NMR}$ spectra. We would also like to thank Ahmed MRABTI, technician at COSTE (Mohamed the 1st University) for the atomic absorption measurements.

\section{Conflicts of Interest}

The authors declare no conflict of interest.

\section{References}

1. Babel, S.; Kurniawan, T.A. Low-cost adsorbents for heavy metal uptake from contaminated water: A review. J. Haz. Mater. 2003, 97, 219-243.

2. Saeed, M.M.; Ahmed, M. Retention, kinetics and thermodynamics pro-file of cadmium adsorption from iodide medium onto polyurethane foam and its separation from zinc bulk. Anal. Chem. Acta 2004, 525, 289-297. 
3. Sanchez, L.R.B.; de La Riva, B.S.V.; Fernandez, J.M.C.; Pereiro, R.; Medel, A.S. Determination of lead and mercury in sea water by preconcentration in a flow injection system followed by atomic adsorption spectrometry detection. Talanta 2001, 55, 1071-1078.

4. Silbergeld, E. The Elimination of Lead from Gasoline: Impacts of Lead in Gasoline on Human Health, and the Costs and Benefits of Elimination Lead Additives, Draft Paper; The World Bank: Washington, DC, USA, 1996; p. 3.

5. Solé, E.; Ballbriga, A.; Dominguez, C. Lead exposure in children: Levels in blood, prevalence of intoxication and related factors. BioMetals 1998, 11, 189-197.

6. Goswami, A.; Singh, A.K. Silica gel functionalized with resacetophenone: Synthesis of a new chelating matrix and its application as metal ion collector for their flame atomic absorption spectrometric determination. Anal. Chim. Acta 2002, 454, 229-240.

7. Melek, E.; Tuzen, M.; Soylak, M. Flame atomic absorption spectrometric determination of cadmium(II) and lead(II) after their solid phase extraction as dibenzyldithiocarbamate chelates on Dowex Optipore V-493. Anal. Chim. Acta 2006, 578, 213-219.

8. Jiang, N.; Chang, X.J.; Zheng, H.; He, Q.; Hu, Z. Selective solid-phase extraction of nickel (II) using a surface-imprinted silica gel sorbent. Anal. Chim. Acta 2006, 577, 225-231.

9. Duan, T.C.; Song, X.J.; Jin, D.; Li, H.F.; Xu, J.W.; Chen, H.T. Preliminary results on the determination of ultratrace amounts of cadmium in tea samples using a flow injection on-line solid phase extraction separation and preconcentration technique to couple with a sequential injection hydride generation atomic fluorescence spectrometry. Talanta 2005, 67, 968-974.

10. Suvardhan, K.; Suresh Kumar, K.; Rekha, D.; Jayaraj, B.; Krishnamurthy, N.G.; Chiranjeevi, P. Preconcentration and solid-phase extraction of beryllium, lead, nickel, and bismuth from various water samples using 2-propylpiperidine-1-carbodithioate with flame atomic absorption spectrometry (FAAS). Talanta 2006, 68, 735-740.

11. Wan, Z.; Xu, Z.R.; Wang, J.H. Flow injection on-line solid phase extraction for ultra-trace lead screening with hydride generation atomic fluorescence spectrometry. Analyst 2006, 131, 141-147.

12. Fang, J.; Iang, Y.J.; Yan, X.P.; Ni, Z.M. Selective quantification of trace palladium in road dusts and roadside soils by displacement solid-phase extraction online coupled with electrothermal atomic absorption spectrometry. Environ. Sci. Technol. 2005, 39, 288-292.

13. Haginaka, J. Selectivty of affinity media in solide-phase extraction of analytes. Trends Anal. Chem. 2005, 24, 407-415.

14. Sarkar, A.R.; Datta, P.K.; Sarkar, M. Sorption recovery of metal ions using silica gel modified with salicyladoxime. Talanta 1996, 43, 1857-1862.

15. Price, P.M.; Clark, J.H.; Macquarrie, D.J. Modified silicas for clean technology. J. Chem. Soc. Dalton Trans. 2000, 101-110, doi:10.1039/A905457J.

16. Grigoropoulou, G.; Stathi, P.; Karakassides, M.A.; Louloudi, M.; Deligibiannakis, Y. Functionalized $\mathrm{SiO}_{2}$ with N-,S-containing ligands for $\mathrm{Pb}(\mathrm{II})$ and $\mathrm{Cd}(\mathrm{II})$ adsorption. Colloids Surf. 2008, 320, 25-35.

17. Fan, J.; Wu, C.; Peng, C.; Peng, P. Preparation of xylenol orange functionalized silica gel as a selective solid phase extractor and application for preconcentration-separtion of mercury from waters. J. Haz. Mater. 2007, 145, 323-330. 
18. Jamali, M.R.; Assadi, Y.; Shemirani, F.; Salavati-Niasari, M. Application of thiophene-2carbaldehyde-modified mesoporous silica as a new sorbent for separation and preconcentration of palladium prior to inductively coupled plasma atomic emission spectrometric determination. Talanta 2007, 71, 1524-1529.

19. Akhond, M.; Absalan, G.; Sheikhian, L.; Eskandari, M.M.; Sharghi, H. Di (n-propyl) thiuram disulfide bonded on silica gel as a new sorbent for separation, preconcentration, and measurement of silver ion from aqueous samples. Sep. Purif. Technol. 2006, 52, 53-59.

20. Amarasekara, A.S.; Owereh, O.S.; Aghara, S.K. Synthesis of 4-acylpyrazolone Schiff base ligand grafted silica and selectivity in adsorption of lanthanides from aqueous solutions. J. Rare Eart. 2009, 27, 870-874.

21. Ngeontae, W.; Aeungmaitrepirom, W.; Tuntulani, T. Chemically modified silica gel with aminothioamidoanthraquinone for solid phase extraction and preconcentration of $\mathrm{Pb}(\mathrm{II}), \mathrm{Cu}(\mathrm{II})$, $\mathrm{Ni}(\mathrm{II}), \mathrm{Co}(\mathrm{II})$ and Cd(II). Talanta 2007, 71, 1075-1082.

22. Goswami, A.; Singh, A.K. 1,8-Dihydroxyanthraquinone anchored on silica gel: Synthesis and application as solid phase extraction for lead(II), Zinc(II) and cadmium(II) prior to determination by flame atomic adsorption spectrometry. Talanta 2002, 58, 669-678.

23. Sadeghi, S.; Sheikhzadeh, E. Solid phase extraction using silica gel modified with murexide for preconcentration of uranium (VI) ions from water samples. J. Haz. Mater. 2009, 163, 861-868.

24. Gubbuk, I.H.; Hatay, I.; Coskun, A.; Ersoz, M. Immobilization of oxime derivative on silica for the preparation of new adsorbent. J. Haz. Mater. 2009, 172, 1532-1537.

25. Sharma, R.K.; Pandey, A.; Gulati, S.; Adholeya, A. An optimized procedure for preconcentration, determination and on-line recovery of palladium using highly selective diphenyldiketonemonothiosemicarbazone modified silica gel. J. Haz. Mater. 2012, 209, 285-292.

26. Mukherjee, R. Coordination chemistry with pyrazol-based chelating ligands: Molecular structural aspects. Coord. Chem. Rev. 2000, 203, 151-218.

27. Trofimenko, S. Recent advances in poly(pyrazolyl)borate (scorpionate) chemistry. Chem. Rev. 1993, 93, 943-980.

28. Trofimenho, S. The coordination chemistry of pyrazole-derived ligands. Prog. Inorg. Chem. 1986, 34, 115-210.

29. Radi, S.; Toubi, Y.; Tighadouini, S.; Baquet, M. Solid-phase extraction of Hg(II), Zn(II) and $\mathrm{Cd}$ (II) from water using silica gel modified with bipyrazolic tripodal receptor. Ind. J. Chem. Tech. 2013, 20, 423-428.

30. Radi, S.; Basbas, N.; Tighadouini, S.; Bacquet, M.; Degoutin, S.; Cazier, F. New amine-modified silica: Synthesis, characterisation and its use in the $\mathrm{Cu}(\mathrm{II})$-Removal from aqueous solutions. Prog. Nanotech. Nanomat. 2013, 2, 108-116.

31. Radi, S.; Toubi, T.; Bacquet, M.; Degoutin, S.; Cazier, F. 1-(Pyridin-2-yl) Imine functionalized silica gel: Synthesis, Characterization and preliminary use in metal ion extraction. Sep. Sci. Tech. 2013, 48, 1349-1355.

32. Radi, S.; Toubi, Y.; Bacquet, M. Synthesis of pyridin-3-yl-functionalized silica as a chelating sorbent for solid-phase adsorption of $\mathrm{Hg}(\mathrm{II}), \mathrm{Pb}(\mathrm{II}), \mathrm{Zn}(\mathrm{II})$ and $\mathrm{Cd}(\mathrm{II})$ from water. Chem. Res. Intermed. 2013, 39, 3791-3802. 


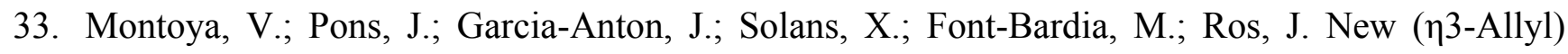
palladium complexes with pyridylpyrazole ligands: Synthesis, characterization, and study of the influence of N1 substituents on the apparent allyl rotation. Organometallics 2007, 26, 3183-3190.

34. Chang, S.-Y.; Chen, J.-L.; Chi, Y.; Cheng, Y.-M.; Lee, G.-H.; Jiang, C.-M.; Chou, P.-T. Blue-emitting platinum(II) complexes bearing both pyridylpyrazolate chelate and bridging pyrazolate ligands: Synthesis, structures and photophysical properties. Inorg. Chem. 2007, 46, 11202-11212.

35. Qu, R.; Wang, M.; Sun, C.; Zhang, Y.; Ji, C.; Chen, H.; Meng, Y.; Yin, P. Chemical modification of silica-gel with hydroxyl- or amino-terminated polyamine for adsorption of Au(III). Appl. Surf. Sci. 2008, 255, 3361-3370.

36. Han, D.M.; Fang, G.Z.; Yan, X.P. Preparation and evaluation of a molecularly imprinted sol-gel material for on-line solid-phase extraction coupled with high performance liquid chromatography for the determination of trace pentachlorophenol in water samples. J. Chromatogr. A 2005, 110, 131-136.

37. Jiang, Y.J.; Gao, Q.M.; Yu, H.G.; Chen, Y.R.; Deng, F. Intensively competitive adsorption for heavy metal ions by PAMAM-SBA-15 and EDTA-PAMAM-SBA-15 inorganic-organic hybrid materials. Micropor. Mesopor. Mater. 2007, 103, 316-324.

38. Abou-El-Sherbini, K.; Kenawy, I.; Hamed, M.; Issa, R.; Elmorsi, R. Separation and preconcentration in a batch mode of $\mathrm{Cd}(\mathrm{II}), \mathrm{Cr}(\mathrm{III}, \mathrm{VI}), \mathrm{Cu}(\mathrm{II}), \mathrm{Mn}(\mathrm{II}, \mathrm{VII})$ and $\mathrm{Pb}(\mathrm{II})$ by solid-phase extraction by using of silica modified with N-propylsalicylaldimine. Talanta 2002, 58, 289-300.

39. Sales, J.A.A.; Airoldi, C. Calorimetric investigation of metal ion adsorption on 3glycidoxypropyltrimethylsiloxane + propane-1,3-diamine immobilized on silica gel. Thermochim. Acta 2005, 427, 77-83.

40. Sales, J.A.A.; Faria, F.P.; Prado, A.G.S.; Airoldi, C. Attachment of 2-aminomethyl-pyridine molecule onto grafted silica gel surface and its ability in chelating cations. Polyhedron 2004, 23, 719-725.

41. Roumeliotis, P.; Kurganov, A.A.; Davankov, V.A. Effect of the hydrophobic spacer in bonded $\left(\mathrm{Cu}\right.$ (L-hydroxyprolyl)alkyl) ${ }^{+}$silicas on retention and enantioselectivity of $\alpha$-amino acids in high-performance liquid chromatography. J. Chromatogr. A 1983, 266, 439-450.

42. Kudryavtsev, G.V.; Milchenko, D.V.; Bernadyuk, S.Z.; Vertinskaya, T.E.; Lisichkin, G.V. Synthesis and properties of phosphate cation-exchangers based on silica. Theor. Exp. Chem. USSR 1988, 23, 658-663.

43. Brunauer, S.; Emmett, P.H.; Teller, E. Adsorption of gases in multimolecular layers. J. Am. Chem. Soc. 1938, 60, 309-319.

44. Banerjee, I.A.; Yu, L.; Matsui, H. $\mathrm{Cu}$ nanocrystal growth on peptide nanotubes by biomineralization: Size control of $\mathrm{Cu}$ nanocrystals by tuning peptide conformation. Proc. Natl. Acad. Sci. USA 2003, 100, 14678-14682.

45. Xue, X.; Li, F. Removal of $\mathrm{Cu}$ (II) from aqueous solution by adsorption onto functionalized SBA-16 mesoporous silica. Micropor. Mesopor. Mater. 2008, 116, 116-122.

46. Pearson, R.G. Hard and soft acids and bases. J. Am. Chem. Soc. 1963, 85, 3533-3539.

47. Myers, R.T. Thermodynamics of chelation. Inorg. Chem. 1978, 17, 952-958.

48. Mahmoud, R.E. Silica gel-immobilized Eriochrome blach-T as a potential solid phase extractor for zinc (II) and magnesium (II) from calcium (II). Talanta 1997, 45, 309-315. 
49. Maquieira, A.; Elmahadi, H.A.M.; Puchades. R. Immobilized cyanobacteria for online trace metal enrichment by flow injection atomic absorption spectrometry. Anal. Chem. 1994, 66, 3632-3638.

50. Lehn, J.M.; Sauvage, J.P. (2)-Cryptates: Stability and selectivity of alkali and alkaline-earth macrobicyclic complexes. J. Am. Chem. Soc. 1975, 97, 6700-6707.

51. Radi, S.; Yahyi, A.; Ramdani, A.; Zidane, I.; Hacht, B. A new tetrapyrazolic macrocycle. Synthesis and its use in extraction and transport of $\mathrm{Na}^{+}, \mathrm{Li}^{+}$, and $\mathrm{K}^{+}$. Tetrahedron 2006, 62, 9153-9155.

52. Radi, S.; Ramdani, A.; Lekchiri, Y.; Morcellet. M.; Crini, G.; Morcellet, J.; Janus, L. New tetrapyrazolic macrocycle. Synthesis and cation binding properties. J. Chem. Res. 2003, 11, 712-714.

53. Radi, S.; Ramdani, A.; Lekchiri, Y.; Morcellet. M.; Crini, G.; Morcellet, J.; Janus, L. New tetrapyrazolic macrocycle. Synthesis and preliminary use in metal ion extraction. Tetrahedron 2004, 60, 939-942.

54. Xie, F.; Lin, X.; Wu, W.; Xie, Z. Solid phase extraction of lead (II), copper (II), cadmium (II), and nickel (II) using gallic acid modified silica gel prior to determination by flame atomic adsorption spectrometry. Talanta 2008, 74, 836-843.

55. Chiron, N.; Guilet, R. Adsorption of $\mathrm{Cu}(\mathrm{II})$ and $\mathrm{Pb}$ (II) onto a grafted silica: Isotherms and kinrtic models. Water Res. 2003, 37, 3079-3086.

56. Radi, S.; Ramdani, A.; Lekchiri, Y.; Morcellet, M.; Crini, G.; Janus, L. Bacquet, M. Immobilization of pyrazole compounds on silica gels and their preliminary use in metal ion extraction. New J. Chem. 2003, 27, 1224-1227.

57. Radi, S.; Attayibat, A. Functionalized $\mathrm{SiO}_{2}$ with S-donor thiophene. Synthesis, Characterisation and its heavy metals adsorption. Phos. Sul. Sil. Relat. Elem. 2010, 185, 2003-2013.

58. Kocjan, R. Retention of some metal ions and their separation on silica gel modified with Acid Red 88. Mikrochim. Acta 1999, 131, 153-158.

59. Zaporozhets, O.; Petruniock, N.; Sukhan, V. Determination of $\mathrm{Ag}(\mathrm{I}), \mathrm{Hg}(\mathrm{II})$ and $\mathrm{Pb}$ (II) by using silica gel loeded with dithizone and zinc dithizonate. Talanta 1999, 50, 865-873.

60. Huang, X.; Chang, X.; He, Q.; Cui, Y.; Zhai, Y.; Jiang, N. Tris(2-aminoethyl) amine functionalized silica gel for solid-phase extraction and preconcentration of $\mathrm{Cr}(\mathrm{II}), \mathrm{Cd}(\mathrm{II})$, and $\mathrm{Pb}$ (II) from waters. J. Haz. Mater. 2008, 157, 154-160.

61. Shahbazi, A.; Younesi, H.; Badiei, A. Functionalized SBA-15 mesoporous silica by melamine-based dendrimer amines for adsorptive characteristics of $\mathrm{Pb}(\mathrm{II}), \mathrm{Cu}(\mathrm{II})$ and $\mathrm{Cd}(\mathrm{II})$ heavy metal ions in batch and fixed bed column. Chem. Eng. J. 2011, 168, 505-518.

62. Fifani, J.; Ramdani, A.; Tarrago, G. 1,6,11,16-Tetraazaporphyrinogen, Synthesis and behavior. New J. Chem. 1977, 1, 521-528.

63. Tarrago, G.; Ramdani, A.; Elguero, J.; Espada, M. Orientation de la réaction d'alkylation des pyrazoles dans des conditions neutres et en catalyse par transfert de phase. J. Heterocycl. Chem. 1980, 17, 137-142.

Sample Availability: Samples of the adsorbents are available from the authors.

(C) 2013 by the authors; licensee MDPI, Basel, Switzerland. This article is an open access article distributed under the terms and conditions of the Creative Commons Attribution license (http://creativecommons.org/licenses/by/3.0/). 